\title{
Gambaran Arus Puncak Ekspirasi (APE) dan Kontrol Asma pada Pasien Asma
}

\author{
Akbar Nur \\ Fakultas Keperawatan, Universitas Airlangga Surabaya; nur188akbar@gmail.com (koresponden) \\ Muhammad Amin \\ Fakultas Kedokteran, Universitas Airlangga Surabaya; muh.amin@fk.unair.ac.id \\ Muhammad Sajidin \\ STIKes Bina Sehat PPNI, Mojokerto; msajidin@yahoo.co.id \\ Kusnanto \\ Fakultas Keperawatan, Universitas Airlangga Surabaya; kusnanto@fkp.unair.ac.id
}

\begin{abstract}
Asthma is a chronic inflammatory airway disease characterized by episodic wheezing, coughing, and chest tightness due to airway obstruction. The aim of this study was to identify the peak expiratory flow (APE) and control of asthma in asthmatic patients at the Poly Paru Airlangga University Hospital and Home Haji General Hospital) Surabaya. This research method was descriptive study with a sample of 78 respondents. APE was measured using a Peak Flow Meter and asthma control using the Asthma Control Test (ACT) questionnaire. This study showed that APE and asthma control in all study subjects were 27-88\% of the standard value. It can be concluded that there was a decrease in Peak Forced Expiration Flow and control of asthma in asthmatic patients. This study is expected to be a source of information for health professionals especially nurses regarding the value of Forced Expiration Peak Flow (APE) and asthma control in asthmatic patients.

Keywords: forced peak expiratory flow (APE); asthma control
\end{abstract}

\begin{abstract}
ABSTRAK
Asma adalah penyakit jalan napas inflamasi kronis yang ditandai dengan mengi episodik, batuk, dan sesak dada akibat obstruksi jalan napas.tujuan penelitian ini adalah untuk mengidentifikasi Arus Puncak Ekspirasi (APE) dan kontrol asma pada pasien asma di poli Paru Rumah Sakit Universitas Airlangga dan Rumah Sakit Umum Haji) Surabaya. Metode penelitian ini studi deskriptif dengan ukran sampel 78 responden. APE diukur menggunakan Peak Flow Meter dan kontrol asma menggunakan kuisioner Asthma Control Test (ACT). Penelitian ini menunjukkan bahwa APE dan kontrol asma pada seluruh subyek penelitian 27-88 \% dari nilai standar.dapat disimpulkan bahwa terdapat penurunan Arus Puncak Ekspirasi Paksa dan kontrol asma pada pasien asma. Penelitian ini diharapkan menjadi sumber informasi bagi tenaga kesehatan khsusnya perawat mengenai nilai Arus Puncak Ekspirasi Paksa (APE) dan kontrol asma pada pasien asma.
\end{abstract}

Kata kunci: arus puncak ekspirasi paksa (APE); kontrol asma

\section{PENDAHULUAN}

\section{Latar Belakang}

Asma merupakan penyakit inflamasi kronis saluran napas yang ditandai dengan mengi episodic, batuk, dan sesak di dada akibat penyumbatan saluran napas besar hingga perifer, beberapa bukti menyatakan bahwa saluran napas kecil memberikan kontribusi terhadap keparahan asma. Pada umumnya penderita asma dapat diterapi secara efektif dengan menggunakan obat-obatan yang saat ini tersedia. Namun ada sebagian penderita asma yang sering kambuh atau tidak terkontrol sehingga menjadi tantangan pengobatan bagi pelayanan $\operatorname{kesehatan}^{(1)}$.

Menurut World Health Organization ${ }^{(2)}$ Penderita asma 235 juta orang, angka kematian akibat asma di Indonesia mencapai 24.773 orang atau sekitar $1,77 \%$ dari total jumlah kematian penduduk, data ini sekaligus menempatkan Indonesia di urutan ke-19 dunia perihal kematian akibat asma. Global Initiative For Asthma ${ }^{(3)}$. Setiap tahun terdapat sekitar 180.000 kematian di seluruh Dunia dari kondisi ini, dan asma telah menjadi penyakit yang serius dalam beberapa tahun terakhir ${ }^{(4)}$. Penelitian telah mengungkapkan bahwa penurunan fungsi paru pada individu dengan asma secara tetap atau riwayat asma pada anak-anak dan dewasa muda. Peradangan saluran napas kronis dapat menyebabkan penurunan fungsi paru jangka Panjang pada pasien asma ${ }^{(5)}$.

Hasil studi pendahuluan di RSUA (Rumah Sakit Universitas Airlangga) berdasarkan hasil observasi dan wawancara dari perawat poli paru RSUA menyebutkan bahwa rata-rata pengunjung pasien asma lama sebanyak 3 orang per hari dan kasus asma baru sebanyak 5 pasien per bulan sehingga dapat disimpulkan bahwa jumlah kunjungan kontrol pasien asma lama dalam satu bulan sebanyak $60(0,6 \%)$ pasien dan $5(0,05 \%)$ kasus asma 
baru untuk di RSU Haji Surabaya menyebutkan bahwa dalam rentang Juli-September 2018 jumlah kunjungan kontrol asma pasien baru maupun lama mencapai $647(6,47 \%)$ pasien, yang terdiri dari $48(0,48 \%)$ kasus asma baru dan $599(5,99 \%)$ kasus asma lama.

Penatalaksanaan asma difokuskan untuk menurunkan gejala, mencegah kekambuhan dan penurunan konsumsi kortikosteroid atau bisa dikatakan asma terkontrol ${ }^{(3)}$. Kontrol asma dapat dilakukan dengan menggunakan berbagai parameter. Salah satu instrument yang sederhana dan sudah memiliki validias adalah Asthma Control Test (ACT). Asthma Control Test merupakan suatu uji skrining berupa kuisioner tentang penilaian klinis seorang penderita asma untuk mengetahui asmanya terkontrol atau tidak. Kuisioner ini terdiri dari lima pertanyaan, yang dikeluarkan oleh America Lung Association bertujuan memberikan kemudahan bagi dokter, perawat, dan pasien untuk mengevaluasi asma penderita yang berusia diatas 12 tahun dan menetapkan terapi pemeliharaannya. Parameter yang dinilai adalah gangguan aktivitas harian akibat asma, gejala malam, penggunaan obat pelega dan persepsi terhadap kontrol asma ${ }^{(2),(7),(8)}$.

Penilaian beratnya gangguan yang terjadi dapat dinilai dengan tes faal paru yaitu dengan pemeriksaan arus puncak ekspirasi paksa. Nilai APE dapat diperoleh melalui pemeriksaan yang lebih sederhana dengan menggunakan Peak Expiratory Flow Meter (PEF meter). Pengukuran volume ekspirasi paksa detik pertama (VEP1) dan kapasitas vital paksa (KVP) dilakukan dengan manuver ekspirasi paksa melalui prosedur yang standar. Pemeriksaan sangat bergantung kepada kemampuan penderita sehingga dibutuhkan instruksi yang jelas dan kooperatif penderita. Untuk mendapatkan nilai yang akurat, diambil nilai tertinggi dari 2-3 nilai yang reproducible dan acceptable. Hasil tes fungsi paru pada pasien asma, dapat diketahui adanya obstruksi jalan napas bila rasio $\mathrm{VEP}_{1}$ (volume ekspirasi paksa detik Pertama) atau kapasitas vital paksa (KVP) $<75 \%$ atau VEP $_{1}<80 \%$ nilai prediksi. ${ }^{(9-11)}$.

Penatalaksanaan asma bertujuan untuk meningkatkan kualitas hidup yang lebih baik dengan asma yang terkontrol. Asma yang tidak terkontrol diakibatkan oleh beberapa komponen, diantaranya kebiasaan merokok, penggunaan obat kortikosteroid yang salah, genetic, pengobatan yang kurang tepat, serta kurangnya pengetahuan mengenai asma.bentuk penatalaksanaan yang dapat dilakukan untuk menghindari adanya kondisi yang memburuk pada pasien asma adalah dengan memperbaiki ventilasi, memperkuat otot pernapasan, dan mencegah terjadinya komplikasi sehingga dapat meningkatkan volume ekspirasi paksa dalam 1 detik $\left(\mathrm{FEV}_{1}\right)$, kontrol asma sehingga terjadi peningkatan kualitas hidup pada pasien asma, untuk mencapai hal tersebut maka penderita asma harus diberikan rehabilitasi pulmonal. ${ }^{(12-14)}$

Serangan asma timbul jika factor pencetus berikatan dengan antibody Ig E yang akan meningkat dalam jumlah besar. Antibody Ig E tersebut akan berikatan dengan antigen spesifik yang melekat pada sel mast yang terdapat dalam intertisial paru yang berhubungan erat dengan bronkiolus dan bronkus kecil. Sel mast akan mengalami degranulasi sehingga mengeluarkan mediator kimia misalnya histamin, zat anafilaksis yang bereaksi lambat, factor kemotaktik eosinofilik, dan bradykinin, efek gabungan dari semua factor ini, terutama substansi anafilaksis yang bereaksi lambat, akan menghasilkan edema local pada dinding bronkus kecil maupun maupun sekresi mucus yang kental kedalam lumen bronkiolus, dan spasme otot polos bronkiolus. Sehingga tahanan saluran napas menjadi sangat meningkat.

\section{Tujuan Penelitian}

Penelitian ini adalah untuk mengidentifikasi Arus Puncak Ekspirasi (APE) dan kontrol asma pada pasien asma di poli Paru Rumah Sakit Universitas Airlangga dan Rumah Sakit Umum Haji) Surabaya.

\section{METODE}

Penelitian ini menggunakan cross sectional design dilakukan pada bulan Januari hingga Maret 2019. Populasi target dalam penelitian ini adalah pasien yang didiagnosis asma di poli paru Rumah Sakit Universitas Airlangga dan Rumah Sakit Umum Haji Surabaya yang menjalani rawat jalan. Sampel penelitian ini sebanyak 78 orang yang memenuhi kriteria inklusi dan eksklusi selama 3 bulan dan tidak ada yang Drop out.

Kriteria inklusi pada penelitian ini adalah pria dan wanita berusia 17-60 tahun, Komunikasi lisan baik, penderita asma stabil dan mampu duduk dan berdiri tanpa bantuan orang lain dan alat. Sedangkan kriteria eksklusi yaitu; penderita asma dalam serangan, pasien dengan sesak napas karena komplikasi penyakit lain, pasien dengan gangguan fisik permanen pada leher, dada, dan ekstremitas atas.

Subyek dalam penelitian ini akan diukur APE dengan menggunakan Peak Flow Meter dengan kriteria:

1. Asma ringan jika nilai APE prediksi $>80 \%$

2. Asma sedang jika nilai APE prediksi $60-80 \%$

3. Asma berat jika nilai APE prediksi $<60 \%$

Penelitian ini telah diajukan kepada Komisi Etik Penelitian Rumah Sakit Universitas Airlangga dengan No. 197/KEH/2018 pada tanggal 11 Desember 2018 dan Rumah Sakit Umum Haji dengan No. 
073/07/KOM.ETIK/2019 pada tanggal 7 Februari 2019 dalam upaya melindungi hak asasi dan kesejahteraan subjek penelitian kesehatan dan telah dinyatakan laik etik.

\section{HASIL}

\section{Karakteristik Subyek Penelitian}

Dari analisis statistik untuk sebaran usia, tingkat Pendidikan, jenis kelamin, pekerjaan dan genetik/riwayat keluarga asma antara kelompok responden Rumah Sakit Universitas Airlangga (RSUA) dan kelompok Rumah Sakit Umum Haji Surabaya menunjukkan data sebagai berikut.

Tabel 1. Karakteristik subyek penelitian di Poli Paru RSUA dan RSU Haji Surabaya

\begin{tabular}{|c|c|c|c|c|}
\hline \multirow[t]{2}{*}{ Karakteristik } & \multicolumn{2}{|c|}{ Rumah Sakit Universitas Airlangga } & \multicolumn{2}{|c|}{ Rumah Sakit Umum Haji Surabaya } \\
\hline & Frekuensi & Persentase & Frekuensi & Persentase \\
\hline \multicolumn{5}{|l|}{ Usia } \\
\hline $17-25$ & 5 & 12.8 & 1 & 2.6 \\
\hline $26-35$ & 7 & 17.9 & & \\
\hline $36-45$ & 9 & 23.1 & 7 & 17.9 \\
\hline $46-60$ & 18 & 46.2 & 31 & 79.5 \\
\hline Total & 39 & 100 & 39 & 100 \\
\hline \multicolumn{5}{|l|}{ Pendidikan } \\
\hline Tidak sekolah & 1 & 2.6 & 1 & 2.6 \\
\hline Pendidikan dasar & 6 & 15.3 & 19 & 48 \\
\hline Pendidikan & 16 & 41.0 & 11 & 28.2 \\
\hline menengah & 16 & 41.0 & 9 & 23.1 \\
\hline \multicolumn{5}{|l|}{ Pendidikan tinggi } \\
\hline Total & 39 & 100 & 39 & 100 \\
\hline \multicolumn{5}{|l|}{ Jenis kelamin } \\
\hline Laki-laki & 10 & 25.6 & 12 & 30.8 \\
\hline Perempuan & 29 & 74.4 & 27 & 69.2 \\
\hline Total & 39 & 100 & 39 & 100 \\
\hline \multicolumn{5}{|l|}{ Pekerjaan } \\
\hline Pns & 4 & 10.3 & 3 & 7.7 \\
\hline Wiraswasta & 7 & 17.9 & 11 & 28.2 \\
\hline Irt/lainnya & 28 & 71.8 & 25 & 64.1 \\
\hline Total & 39 & 100 & 39 & 100 \\
\hline \multicolumn{5}{|l|}{$\begin{array}{l}\text { Riwayat keluarga } \\
\text { asma }\end{array}$} \\
\hline $\mathrm{Ya}$ & 30 & 76.9 & 28 & 71.8 \\
\hline Tidak & 9 & 23.1 & 11 & 28.2 \\
\hline Total & 39 & 100 & 39 & 100 \\
\hline
\end{tabular}

Tabel 1 menunjukkan bahwa karakteristik usia responden berdasarkan usia, responden terbanyak pada kelompok responden RSUA dan RSU Haji mayoritas berada pada rentang usia 46-60 Tahun yaitu 18 (46.2 pada kelompok responden RSUA dan 31 (79.5\%) kelompok RSU Haji yang merupakan kategori usia masa lansia awal dan lansia akhir. Responden pada kelompok RSUA mayoritas berpendidikan menengah 14 (41.2\%) dan pada kelompok RSU Haji mayoritas berpendidikan dasar sebanyak 19 subyek (50.0\%). Karakteristik jenis kelamin pada kedua kelompok mayoritas perempuan, pada kelompok responden RSUA sebanyak 29 (74.4\%) perempuan sedangkan pada kelompok responden RSU Haji sebanyak 27 (69.2\%). Karakteristik pekerjaan pada kelompok responden RSUA dan RSU Haji sebagaian besar sebagai IRT/lainnya, pada kelompok responden RSUA sebanyak 28 subyek (71.8\%) dan kelompok responden RSU Haji sebanyak 25 (64.1\%). Karakteristik responden berdasarkan riwayat keluarga yang menderita asma (genetik) pada kelompok responden RSUA sebanyak 30 subyek (76.9 \%) dan kelompok responden RSU Haji sebanyak 28 subyek (71.8\%) yang memiliki riwayat keluarga/genetik yang menderita asma.

Table 2 menunjukkan bahwa responden RSUA terdapat 15 (38.5\%) asma sedang, 14 (35.9\%) responden asma berat dan $10(25.6 \%)$ responden berada pada skala asma ringan. Pada kelompok responden RSU Haji Surabaya terdapat $21(53.8 \%)$ responden asma berat, 14 (35.9\%) asma sedang dan $4(10.3 \%)$ responden dengan skala asma ringan. 
Table 2. Distribusi skala asma pada kelompok responden Rumah Sakit Universitas Airlangga dan Rumah Sakit Umum Haji Surabaya

\begin{tabular}{|c|c|c|c|c|}
\hline \multirow{2}{*}{ Skala asma } & \multicolumn{2}{|c|}{ Rumah Sakit Universitas Airlangga } & \multicolumn{2}{c|}{ Rumah Sakit Umum Haji Surabaya } \\
\cline { 2 - 5 } & Frekuensi & Persentase & Frekuensi & Persentase \\
\hline Berat & 14 & 35.9 & 21 & 53.8 \\
\hline Sedang & 15 & 38.5 & 14 & 35.9 \\
\hline Ringan & 10 & 25.6 & 4 & 10.3 \\
\hline
\end{tabular}

Tabel 3. Distribusi Nilai APE Ukur (L) dan APE Prediksi (\%) pada kelompok responden RSUA dan RSU Haji Surabaya.

\begin{tabular}{|c|c|c|c|c|}
\hline \multirow{2}{*}{ Nilai APE } & \multicolumn{2}{|c|}{ Rumah Sakit Universitas Airlangga } & \multicolumn{2}{c|}{ Rumah Sakit Umum Haji Surabaya } \\
\cline { 2 - 5 } & Mean \pm SD & Min-Maks & Mean \pm SD & Min-Maks \\
\hline Nilai APE Ukur (L) & $295.77 \pm 63.872$ & $170-450$ & $243.33 \pm 49.542$ & $160-350$ \\
\hline Nilai APE Prediksi (\%) & $65.37 \pm 18.398$ & $20-0.96$ & $57.79 \pm 15.399$ & $27-88$ \\
\hline
\end{tabular}

Tabel 3 menunjukkan bahwa pada kelompok responden RSUA nilai mean APE ukur (L) 295.77 \pm 63.872 dan nilai maksimal 450. Pada kelompok responden RSU Haji nilai ukur APE ukur (L) $243.33 \pm 49.542$ dan nilai maksimal 350. Pada nilai APE prediksi (\%) kelompok responden RSUA didapatkan nilai APE prediksi $65.37 \pm 18.398 \%$ dan nilai maksimal $96 \%$. Pada kelompok responden RSU Haji Surabaya didapatkan nilai Mean APE prediksi $57.79 \pm 15.399 \%$ dan nilai maksimal APE prediksi $88 \%$.

Tabel 4. Distribusi kontrol asma pada kelompok responden RSUA dan RSU Haji Surabaya

\begin{tabular}{|c|c|c|c|c|}
\hline \multirow{2}{*}{ Kontrol asma } & \multicolumn{2}{|c|}{ Rumah Sakit Universitas Airlangga } & \multicolumn{2}{c|}{ Rumah Sakit Umum Haji Surabaya } \\
\cline { 2 - 5 } & Frekuensi & Persentase & Frekuensi & Persentase \\
\hline Tidak terkontrol & 32 & 82.1 & 39 & 100 \\
\hline Terkontrol sebagian & 7 & 17.9 & 0 & 0 \\
\hline Terkontrol penuh & 0 & 0 & 0 & 0 \\
\hline
\end{tabular}

Berdasarkan hasil analisis didapatkan mayoritas responden berada pada asma yang tidak terkontrol. Tabel diatas menunjukkan bahwa pada kelompok responden RSUA terdapat $32(82.1 \%)$ responden yang asmanya berada pada kriteria asma tidak terkontrol dan 7 (17.9\%) responden berada pada asma yang terkontrol sebagian. Pada kelompok responden RSU Haji seluruh responden 39 (100 \%) yang asmanya berada pada asma yang tidak terkontrol dan tidak terdapat responden yang asmanya berada pada kriteria terkontrol penuh.

Tabel 5. Analisis data interval kontrol asma pada kelompok responden RSUA dan RSU Haji Surabaya

\begin{tabular}{|c|c|c|c|}
\hline \multicolumn{2}{|c|}{ Rumah Sakit Universitas Airlangga } & \multicolumn{2}{c|}{ Rumah Sakit Umum Haji Surabaya } \\
\hline Mean \pm SD & Min-Maks & Mean \pm SD & Min-Maks \\
\hline $15.62 \pm 4.089$ & $5-22$ & $14.67 \pm 2.421$ & $10-19$ \\
\hline
\end{tabular}

Setelah dilakukan analisis didapatkan nilai mean kontrol asma 15.62 \pm 4.089 dan nilai maksimal 22 pada kelompok responden RSUA. Pada kelompok responden RSU Haji didapatkan nilai mean 14.67 \pm 2.421 dan nilai maksimal 19.

\section{PEMBAHASAN}

Pada penelitian ini, berdasarkan hasil analisis distribusi frekuensi (tabel 1) dapat dilihat bahwa sebagian besar subyek penelitian berusia 45-60 tahun yang merupakan kategori usia masa lansia awal dan lansia akhir. Hasil penelitian ini sejalan dengan penelitian ${ }^{(15)}$, terjadi penurunan elastisitas alveoli, penebalan kelenjar bronkial, penurunan kapasitas paru dan peningkatan ruang rugi selama proses penuaan. Hal ini disebabkan pada lansia akan terjadi proses menua yang ditandai dengan tahapan menurunnya berbagai struktur dan fungsi sel, jaringan, serta system organ ${ }^{(16)}$.

Responden pada kelompok RSUA mayoritas berpendidikan menengah dan pada kelompok RSU Haji mayoritas berpendidikan dasar sebanyak (tabel 1). Hasil penelitian ini sejalan dengan ${ }^{(17)}$ yang menyatakan bahwa Pendidikan seseorang akan mempengaruhi pola pikir, semakin tinggi Pendidikan seseorang akan semakin baik pemikiran maupun tingkah laku. Semakin baik pengetahuan yang dimiliki seorang penderita asma, baik 
cara penggunaan obat, proses terjadi asma, faktor pencetus, gejala yang timbul, maka cenderung makin baik pula tingkat kontrol asmanya. ${ }^{(18)}$

Berdasarkan pekerjaan, kelompok responden RSUA dan kelompok responden RSU Haji, yang paling banyak yaitu IRT/lainnya (tabel 1). Hasil penelitian ini sejalan dengan penelitian ${ }^{(19)}$ tentang pengetahuan asma, yang termasuk didalamnya bahwa status pekerjaan. Dimana pekerjaan yang baik cenderung di dasari dengan tingkat pengetahuan yang baik pula.

Pada penelitian ini, jumlah perempuan yang menderita asma lebih banyak daripada laki-laki (tabel 1) perempuan cenderung lebih besar menderita asma dibandingkan laki-laki. Hiperesponsif bronkus non-spesifik ditemukan lebih sering pada perempuan daripada laki-laki. Perempuan juga memiliki caliber saluran pernapasan yang lebih kecil dibandingkan laki-laki ${ }^{(20)}$. Laki-laki memiliki kapasitas inspirasi lebih besar dibandingkan dengan perempuan dikarenakan kekuatan otot laki-laki lebih besar dibandingkan perempuan, termasuk otot $\operatorname{pernapasan}^{(21)}$.

Karakteristik responden berdasarkan genetik/riwayat keluarga asma, mayoritas responden mempunyai riwayat keluarga asma dari orang tua (tabel 1) orang tua yang menderita asma merupakan faktor yang kuat terhadap kejadia asma. Banyak gen yang terlibat pada proses pathogenesis asma dan kromosom memiliki potensi untuk menyebabkan asma ${ }^{(22)}$.

Tabel 1.3 menunjukkan bahwa mayoritas responden RSUA berada pada kategori asma sedang dan pada kelompok responden RSU Haji Surabaya, berada pada kategori asma berat. Hal ini disebabkan karena responden RSU Haji mayoritas berusia 46-60 Tahun. Serangan asma menyebabkan pembebasan mediator yang dapat mengubah tonus dan kepekaan otot polos saluran pernapasan yang menyebabkan hipersekresi mucus, dan menimbulkan kerusakan epitel saluran pernapasan, sehingga proses ini mengakibatkanarsitektur dan fungsi saluran napas terganggu secara kronik.

Pada kelompok responden RSUA memiliki nilai mean $295.77 \pm 63.872$ dan nilai maksimal 450. Pada kelompok responden RSU Haji Surabaya nilai ukur APE ukur (L) 243.33 \pm 49.542 dan nilai maksimal 350. Maka dapat disimpulkan pasien RSUA memiliki nilai mean dan nilai maksimal APE lebih tinggi dibandingkan kelompok responden RSU Haji. Pada nilai APE prediksi (\%) kelompok responden RSUA didapatkan nilai mean $65.37 \pm 18.398 \%$ dan nilai maksimal 96\%. Pada kelompok responden RSU Haji Surabaya didapatkan nilai Mean APE prediksi $57.79 \pm 15.399 \%$ dan nilai maksimal APE prediksi $88 \%$. Maka dapat disimpulkan pasien RSUA memiliki nilai mean dan nilai maksimal APE prediksi lebih tinggi dibandingkan kelompok responden RSU Haji.

Arus puncak ekspirasi paksa merupakan titik tertinggi yang dapat dicapai selama ekspirasi maksimal. Pada kejadian asma terjadi resistensi aliran udara yang besar terutama saat ekspirasi, apabila seseorang melakukan ekspirasi mencapai aliran maksimum di mana aliran tidak dapat ditingkatkan lagi walaupun dengan peningkatan tenaga yang maksimal ${ }^{(23)}$.

Selama diluar serangan penderita tampak seperti dalam kondisi sehat dan untuk nilai APE prediksi berbeda dengan orang normal, dimana ketika diluar serangan APE nilai prediksi penderita asma mengalami penurunan $^{(24)}$. Saluran napas yang mengalami penurunan ruang mengakibatkan aliran ekspirasi maksimum juga menjadi berkurang. Ekspirasi maksimal dapat dicapai apabila tidak terjadi perburukan napas dan pengurangan ruang di saluran pernapasan ${ }^{(15)}$.

Penilaian tingkat kontrol asma menggunakan ACT (Asthma Control Test) terdapat beberapa hal yang dinilai yakni intensitas kekambuhan asma dalam melakukan pekerjaan sehari-hari, mengalami sesak napas, terbangun pada malam hari, penggunaan obat dan tingkat kontrol asma. Pada beberapa pertanyaan pada ACT berkaitan dengan eksaserbasi/kekambuhan asma yaitu sebuah proses serangan berulang akibat hiperesponsif sel imun tubuh seperti sel mast, eosinophil dan limfosit $T$, sel mast, makrofag, sel dendritic, dan miofibroblas terhadap stimulus tertentu sehingga menyebabkan gejala sesak napas, wheezing dan batuk yang merupakan akibat dari terjadinya penyempitan jalan napas. ${ }^{(25),(26)}$

Berdasarkan hasil analisis didapatkan rerata responden berada pada asma yang tidak terkontrol. Pada (tabel 5). Pada kelompok responden RSUA didapatkan nilai mean kontrol asma $15.62 \pm 4.089$ dan nilai

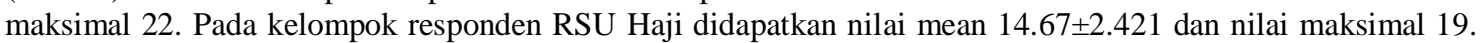
Maka dapat disimpulkan pasien RSUA memiliki nilai mean dan nilai maksimal kontrol asma lebih tinggi dibandingkan kelompok responden RSU Haji. Hal ini disebabkan bahwa tingkat Pendidikan dan usia responden RSUA lebih baik dibandingkan dengan kelompok responden RSU Haji. Asma yang terkontrol sangat dipengaruhi oleh tingkat pengetahuan seorang pasien asma tentang riwayat penyakitnya.

\section{KESIMPULAN}

Penelitian ini menunjukkan bahwa APE dan kontrol asma pada seluruh subyek penelitian 27-88 \% dari nilai standar.dapat disimpulkan bahwa terdapat penurunan Arus Puncak Ekspirasi Paksa dan kontrol asma pada pasien asma. penelitian ini diharapkan menjadi sumber informasi bagi tenaga kesehatan khsusnya perawat mengenai nilai Arus Puncak Ekspirasi Paksa (APE) dan kontrol asma pada pasien asma. 


\section{DAFTAR PUSTAKA}

1. Wener RRL, Bel EH. Severe refractory asthma: An update. Eur Respir Rev. 2013;22(129):227-35.

2. WHO. WHO | Bronchial asthma [Internet]. WHO. World Health Organization; 2018 [cited 2018 Nov 3 ]. Available from: http://www.who.int/mediacentre/factsheets/fs206/en/

3. GINA. Global Strategy for Asthma Management and Prevention. 2018.

4. Parmar J, Nagarwala R. Effects of Pranayama on Bronchial Asthma. Int J Physiol. 2014;2(1):96.

5. Chen Y, Rennie DC, Pahwa P, Dosman JA. Pulmonary function in adults with recent and former asthma and the role of sex and atopy. BMC Pulm Med. 2012;12.

6. Quirt J, Hildebrand KJ, Mazza J, Noya F, Kim H. Asthma. Allergy, Asthma Clin Immunol [Internet]. 2018;14(S2):50. Available from: https://aacijournal.biomedcentral.com/articles/10.1186/s13223-018-02790

7. Allen W. Korelasi Penilaian Asma Terkontrol pada Penderita Asma Persisten Sesudah Pemberian Kortikosteroid Inhalasi dengan Menggunakan Asthma Control Scoring Sytem dan Asthma Control Test. J Kedokt Indones. 2009;

8. Zaini J. Asthma Control Test: Cara Simpel dan Efektif untuk Menilai Derajat dan Respons. J Respirologi Indones. 2011;31:51-2.

9. Adeniyi BO, Erhabor GE. The peak flow meter and its use in clinical practice. African J Respir Med. 2011;5-8.

10. PDPI. Pedoman Praktis Diagnosis dan Penatalaksanaan di Indonesia. Jakarta Dep Kesehat Republik Indones. 2012;

11. Singh S, Soni R, Singh KP, Tandon OP. Effect of yoga practices on pulmonary function tests including transfer factor of lung for carbon monoxide (TLCO) in asthma patients. Indian J Physiol Pharmacol. 2012;56(1):63-8.

12. Black JM, Hawks JH. Keperawatan medikal bedah: manajemen klinis untuk hasil yang diharapkan. Elsevier (Singapore); 2014.

13. José A, Holland AE, Oliveira CS d., Selman JPR, Castro RAS d., Athanazio RA, et al. Does home-based pulmonary rehabilitation improve functional capacity, peripheral muscle strength and quality of life in patients with bronchiectasis compared to standard care? Brazilian J Phys Ther [Internet]. 2017;21(6):47380. Available from: http://dx.doi.org/10.1016/j.bjpt.2017.06.021

14. Cebrià I Iranzo MDÀ, Arnall DA, Camacho CI, Tomás JM. Effects of inspiratory muscle training and yoga breathing exercises on respiratory muscle function in institutionalized frail older adults: A randomized controlled trial. J Geriatr Phys Ther. 2014;37(2):65-75.

15. Hall JE. Guyton and Hall textbook of medical physiology e-Book. Elsevier Health Sciences; 2015.

16. Fatmah D, SKM MS. Gizi Usia Lanjut. Jakarta Erlangga. 2010;

17. Dorevitch S, Karandikar A, Washington GF, Walton GP, Anderson R, Nickels L. Efficacy of an outdoor air pollution education program in a community at risk for asthma morbidity. J Asthma. 2008;45(9):83944.

18. Pohan MYH, Yunus F, Wiyono WH. Asma dan polusi udara. Cermin Dunia Kedokt. 2003;(141):27-9.

19. Zainoel, Rsud, Banda, Abidin. Tingkat Kontrol Asma Di Poliklinik Paru. 2014;139-45.

20. Atmoko W, Faisal HKP, Bobian ET, Adisworo MW, Yunus Faisal. Prevalens asma tidak terkontrol dan faktor-faktor yang berhubungan dengan tingkat kontrol asma di poliklinik asma rumah sakit persahabatan, jakarta. J Respir Indo. 2011;31(2):53-60.

21. Ristianingrum I. Hubungan Indeks Massa Tubuh (IMT) Dengan Tes Fungsi Paru. Univ Jendral Soedirman Skripsi Fak Kedokteran Univ Jendral Soedirman. 2010;

22. Andayani N. ( WHO ) prevalensi obesitas di seluruh bersifat episodik, gejala berupa batuk, menegakkan diagnosis, ditambah dengan sepanjang hari sehingga pemeriksaan fisik objektif ( faal paru ) telah terdapat. 2017;54-9.

23. Moore WC, Castro M. The Many "Buckets" of Severe Asthma: Moving Toward Personalized Management. J Allergy Clin Immunol Pract [Internet]. 2017;5(4):936-7. Available from: http://dx.doi.org/10.1016/j.jaip.2017.05.017

24. Supriyatno B. Combination Therapy of Acute Asthma Attack in Children. J Indones Med Assoc. 2011;60(05).

25. Ghebre MA, Bafadhel M, Desai D, Cohen SE, Newbold P, Rapley L, et al. Biological clustering supports both "dutch" and "british" hypotheses of asthma and chronic obstructive pulmonary disease. J Allergy Clin Immunol [Internet]. 2015;135(1):63-72.e10. Available from: http://dx.doi.org/10.1016/j.jaci.2014.06.035

26. Grzela K, Zagorska W, Krejner A, Litwiniuk M, Zawadzka-Krajewska A, Banaszkiewicz A, et al. Prolonged Treatment with Inhaled Corticosteroids does not Normalize High Activity of Matrix Metalloproteinase-9 in Exhaled Breath Condensates of Children with Asthma. Arch Immunol Ther Exp (Warsz). 2015;63(3):231-7. 